\title{
Lepromatous leprosy simulating rheumatoid arthritis - Report of a neglected disease*
}

\author{
Tatiana Cristina Pedro Cordeiro de Andrade ${ }^{1}$ \\ Bruna Cortinóvis Vieira ${ }^{1}$ \\ Cleverson Teixeira Soares ${ }^{1}$
}

\author{
Tábata Yamasaki Martins ${ }^{1}$ \\ Tatiane Meira Santiago ${ }^{1}$ \\ Jaison Antônio Barreto ${ }^{1}$
}

DOI: http:/ /dx.doi.org/10.1590/abd1806-4841.20175423

\begin{abstract}
Brazil has the second largest number of leprosy cases in the world; nevertheless, late diagnosis is common. We report the case of a male patient with pain and numbness in both hands and feet for six years with positive rheumatoid factor and anticardiolipin under rheumatoid arthritis treatment for five years. Examination revealed diffuse cutaneous infiltration and leonine facies, characteristic features of lepromatous leprosy. Autoantibodies such as rheumatoid factor and anticardiolipin are markers of rheumatic autoimmune diseases, but their presence is also described in leprosy. We report the present case in order to alert health professionals to remember leprosy, even in areas where the disease is considered eliminated as a public health problem, avoiding misinterpretations of serologic findings and misdiagnosis.
\end{abstract}

Keywords: Hansen's disease; Mycobacterium leprae; Rheumatoid arthritis; Rheumatoid factor

\section{INTRODUCTION}

Leprosy is an infectious disease with chronic evolution caused by the bacillus Mycobacterium leprae. It has varied diverse clinical presentation, with events ranging from tuberculoid and lepromatous leprosy. Brazil has the second-largest number of leprosy cases in the world. ${ }^{1}$ The ignorance of the condition by the population, and even by doctors, especially where the disease is considered eliminated as a public health problem, contribute to bacillus maintenance and late diagnosis. ${ }^{2,3}$ Another factor that may contribute to the delay in diagnosis is the fact that autoantibodies can be found in patients with Hansen's disease at higher rates than in the normal population. A clinical picture of lepromatous leprosy associated with articular manifestations, which are also common in these patients, may lead to misdiagnosis and delay the onset of treatment. ${ }^{4,5}$ We report a case of lepromatous leprosy simulating rheumatoid arthritis (RA) aiming at alerting health professionals that leprosy is a great mimicking disease in order to avoid misinterpretations of serologic findings.

\section{CASE REPORT}

We report a 51-year-old male patient from Jau (SP) complaining of pain and numbness in hands for six years. He reported treatment for RA with hydroxychloroquine due to articular disease associated with positive rheumatoid factor test, without improvement. Physical examination revealed an emaciated patient with diffuse cutaneous infiltration and changes in thermal and pain sensitivity tests. We also observed ulcers on hands and feet and foot drop to the right associated with perforating plantar ulceration in the lateral metatarsal region of the right foot. Hands showed swan neck deformity of the fingers with resorption of the distal phalanges, especially to the left. The face showed skin infiltration, nasal septum collapse without perforation, ectropion, and madarosis, producing a leonine resemblance (Figure 1). Hand and foot esthesiometry could not be performed due to the extensive ulcerations present. After the strongly suggestive hypothesis of lepromatous leprosy, we performed a skin biopsy on the right elbow, which confirmed the disease (Figures 2 and 3); bacilloscopy result was 6+; ELISA NDO-BSA antiPGL1 serology was positive, 0.820 (cut off = 0.150); Mitsuda test was negative. In general laboratory tests, blood count showed anemia of chronic disease ( $\mathrm{Hb} 9.6 \mathrm{~g} / \mathrm{dL}, \mathrm{MCV} 80$, $\mathrm{MCH} 28$ with normal serum iron and high ferritin), average white blood cell count, and liver and kidney function without changes. Serology for HIV and hepatitis B and C were negative. Laboratory tests for autoimmune diseases showed C-reactive protein $=22.69$ (normal up to $5 \mathrm{mg} / \mathrm{L}$ ), ESR $=118 \mathrm{~mm}$, positive $\mathrm{RF}$, anticardiolipin IgG (ACL), positive lupus anticoagulant, and negative antinuclear antibodies (ANA) test. VDRL was positive (1:4) with negative FTAabs test. On radiographs of the hands, we observed resorption of the distal phalanges of the fingers (Figure 4). We initiated a multibacil-

Received on 23.11.2015

Approved by the Advisory Board and accepted for publication on 15.02.2016

* Work performed at Instituto Lauro de Souza Lima (ILSL) - Bauru (SP), Brazil. Financial support: none.

Conflict of interest: none.

1 Department of Dermatology at Instituto Lauro de Souza Lima (ILSL) - Bauru (SP), Brazil.

(C)2017 by Anais Brasileiros de Dermatologia 
lary multidrug therapy with great clinical improvement in the first month of treatment (Figure 5). We also prescribed special footwear (Carville sandal with a Harris right mat). The patient is currently being monitored.

\section{DISCUSSION}

Brazil has achieved, at the end of 2015, the goal of eliminating leprosy as a public health problem (defined as a prevalence of less than 1 case per 10,000 population). However, the disease is unevenly distributed in the country. The prevalence rate in east Brazil,
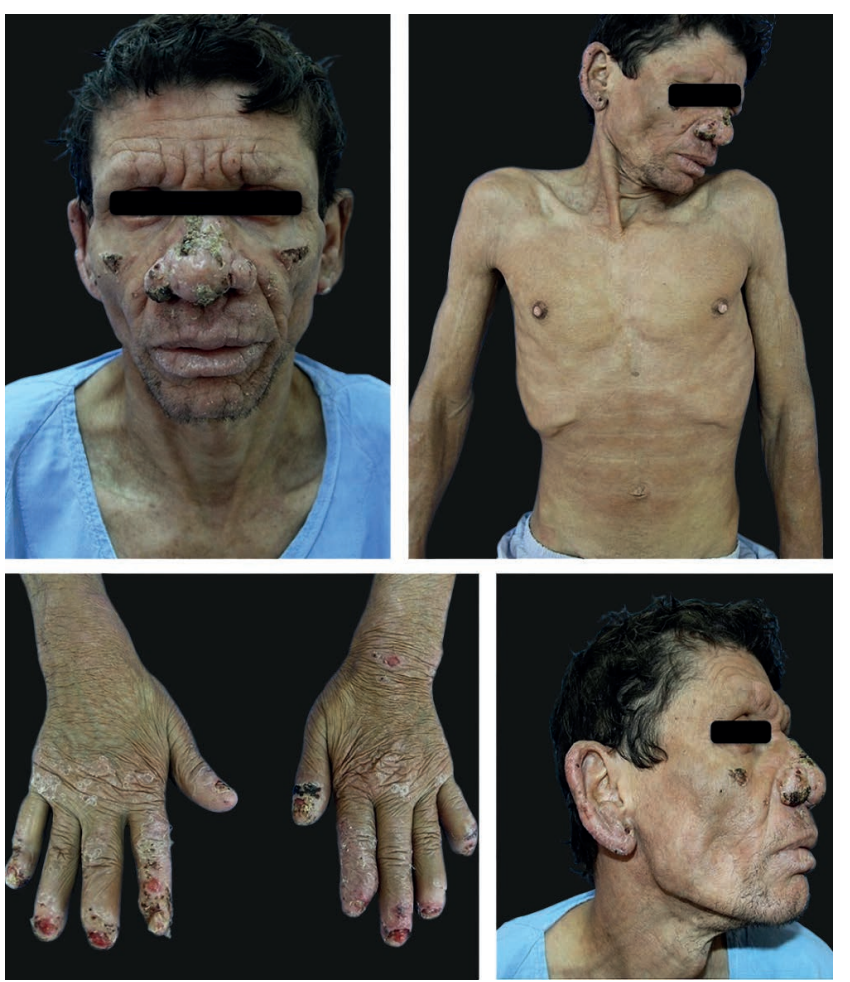

Figure 1: Patient before the treatment: the face showed skin infiltration, nasal septum collapse without perforation, ectropion, and madarosis, producing a leonine resemblance; diffuse cutaneous infiltration; multiple ulcers on fingers and resorption of the distal phalanges, mostly to the left
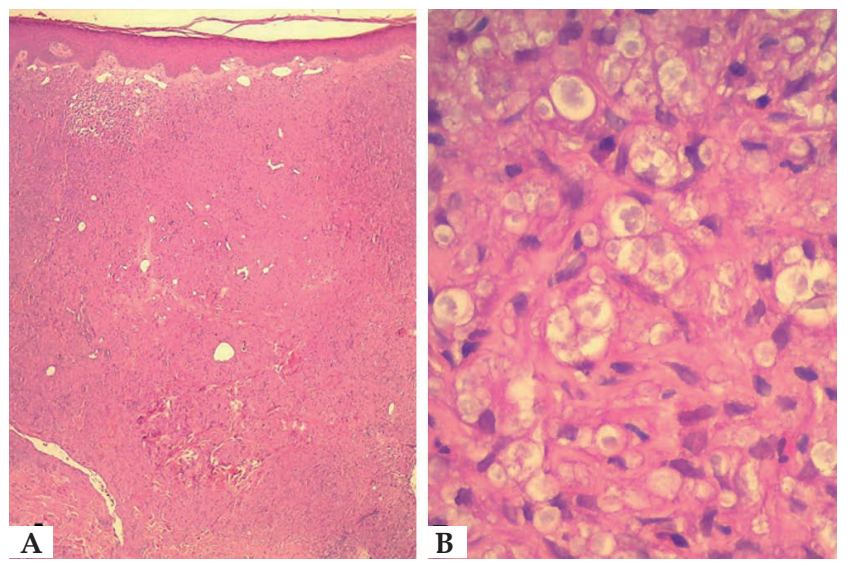

Figure 2: A: (Hematoxylin \& eosin x20) - Epidermal atrophy, Unna band, diffuse histiocytic infiltrate in the full extent of the dermis and subcutaneous tissue. B: ( Hematoxylin \& eosin x400) - Detail of multivacuolated macrophages (Virchow's cells).

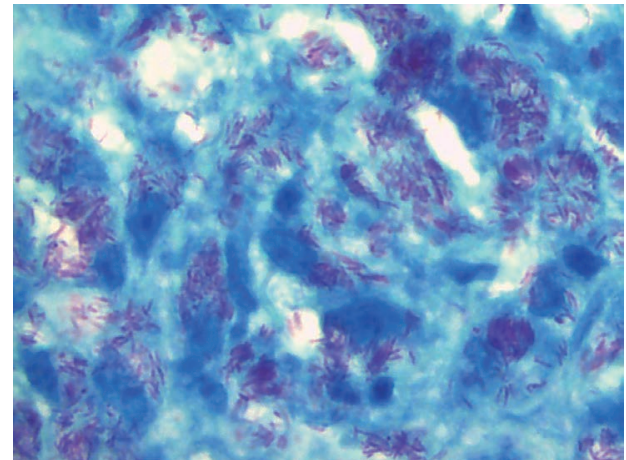

FiguRE 3: Fite-Faraco 1000x - Large numbers of acid-fast stained solid bacilli, with globi formation



FIGURE 4: Radiographs of the hands showing resorption of the distal phalanges of the fingers
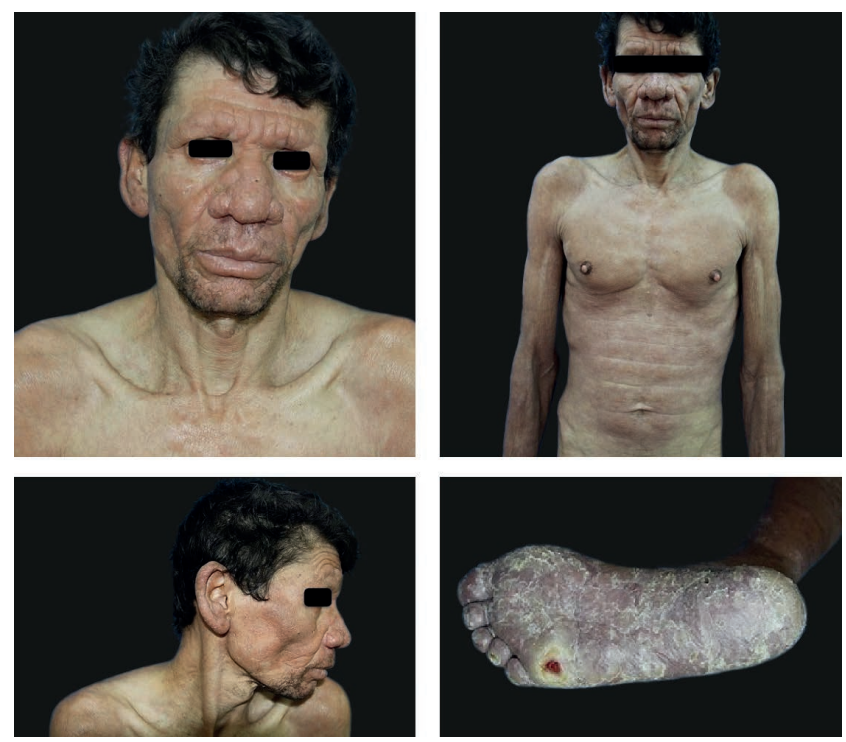

FIGURE 5: Patient one month after starting treatment showing evident improvement with reduced skin infiltration 
the region of the present case, is of 0.61 . Even with prevalence rates below national levels, we still find advanced cases like this, showing real negligence and lack of medical training regarding leprosy. ${ }^{2}$ The present case highlights the importance of maintaining public health actions aimed at the early detection of leprosy.

Leprosy has varied clinical presentations. ${ }^{2,6,7}$ In the lepromatous type, lesions tend to be multiple (lepromas). It may also present itself with no visible lesions and mild frankly diffuse infiltration. Distal symmetric hypoesthesia is common, resembling other diseases that progress to polyradiculoneuropathies, such as diabetes and hypothyroidism. In advanced stages, the face can have a leonine appearance with involvement of mucous membranes, eyes, bones and joints, among others. ${ }^{2}$ It is noteworthy, in this case, the important resorption of the distal phalanges of the fingers and the presence of swan neck deformity of the fingers. The latter is caused by a myositis and specific enthesitis of the intrinsic muscles of the hand, which can be justified by intense inflammatory activity secondary to lepromatous leprosy, confirmed by very high values of ESR and CRP.

Joint involvement in lepromatous leprosy is considered its third most frequent manifestation, after dermatologic and neurological manifestations. ${ }^{4,7,8}$ However, studies show that there is no correlation between the occurrence of arthritis in leprosy and the presence of RF, justified by the fact that most cases of arthritis in these patients are infectious. ${ }^{4,5,7}$

Autoantibodies such as ANA, ACL, and RF are considered markers of rheumatic autoimmune diseases. ${ }^{4}$ Nevertheless, the positivity of these autoantibodies has also been described in a number of infectious diseases such as malaria, bacterial endocarditis, tuberculosis, and leprosy. ${ }^{3-5,8,9}$ Several other autoantibodies were identi- fied in patients with leprosy, including thyroglobulin, anti-smooth muscle, as well as false positive reactions for syphilis, as we observed in our case. ${ }^{3,5}$

The origin of autoantibodies in leprosy is still not well established and may be due to the polyclonal activation of B cells by components of the bacteria or due to the presence of cross-reaction between bacterial antigens and autoantigens. ${ }^{4,7}$ According to Dacas et al., these autoantibodies appear in similar frequency in both lepromatous and tuberculoid types. ${ }^{4}$ However, most authors report a higher frequency in the lepromatous type and agree that their positivity is greater in chronic diseases. ${ }^{3-5,7-9}$ As an exception to most studies, Ribeiro et al. found similar values of RF positivity among leprosy patients and control groups. ${ }^{7}$

The clinical presentation of the patient was virtually diagnostic of lepromatous leprosy. Although the association between RA and leprosy is described, in the present case, it was unlikely due to the skin changes, to the non-improvement with specific therapy for RA, and to the dramatic improvement after the start of multidrug therapy. ${ }^{10}$ The present report highlights the importance of physicians being aware of the high incidence of RF and other autoantibodies in leprosy when treating patients with joint complaints. We emphasize the fact that leprosy is a great mimicking disease in order to avoid misinterpretations of serologic findings and to prevent diagnostic errors. ${ }^{4}$

"It is possible that leprosy be eradicated without us knowing all its secrets, but it is also possible that it will not be eliminated just because we do not know it the way we should" (Professor Opromolla). ${ }^{6}$

\section{REFERENCES}

1. D'Abreu PC, Durães SMB, Estrela RR, Baltazar MCNP, Rochael MC. Hanseníase virchowiana diagnosticada através de exame histopatológico de lesão oral em paciente com pênfigo foliáceo. An Bras Dermatol. 2000;75:339-46.

2. Lastória JC, Morgado de Abreu MAM. Hanseníase: revisão dos aspectos epidemiológicos, etiopatogênicos e clínicos. Parte I. An Bras Dermatol. 2014;89:205-19

3. Azulay RD. Doença auto-agressiva hansênica. An Bras Dermatol 1981;56:159-64.

4. Dacas P, Picanso M, Mouchaileh G, Percegona L, Schultz MT, Silva MGB, et al. Auto-anticorpos e manifestações reumáticas em pacientes com mal de Hansen. An Bras Dermatol. 2000;75:553-61.

5. Cossermelli-Messina W, Cossermelli W. Humoral immunity in Hansen's Disease. São Paulo Med J. 1995;113:929-34.

6. Opromolla DVA. Clínica da hanseníase. Hansenol Int. 2001;26:1-4.

7. Ribeiro SLE, Pereira HLA, Silva NP, Sato El. Autoantibodies in leprosy patients, with and without joint involvement, in the state of Amazonas. Rev. Bras Reumatol. 2009; 49:547-61.

8. Chavez-Legaspi M, Gomez-Vazquez A, García-De La Torre I. Study of rheumatic manifestations and serologic abnormalities in patients with lepromatous leprosy. J Rheumatol. 1985;12:738-41.

9. Garcia-De La Torre I. Autoimune phenomena in leprosy, particularly antinuclear antibodies and rheumatoid factor. J Rheumatol. 1993;20:900-3.

10. Freitas DS, Machado N, Andrigueti FV, Reis Neto ET, Pinheiro MM. Hanseníase virchowiana associada ao uso de inibidor do fator de necrose tumoral $\alpha$ : relato de caso. Rev Bras Reumatol. 2010; 50:333-9.

\author{
MAILING ADDRESS: \\ Tatiana Cristina Pedro Cordeiro de Andrade \\ Rodovia Comandante João Ribeiro de Barros, km 225/226 \\ 17034-971 - Bauru - SP \\ Brazil \\ E-mail: tatianap.andrade@gmail.com
}

How to cite this article: Andrade TCPC, Martins TY, Vieira BC, Santiago TM, Soares CT, Barreto JA. Lepromatous leprosy simulating rheumatoid arthritis - Report of a neglected disease. An Bras Dermatol. 2017;92(3):389-91. 